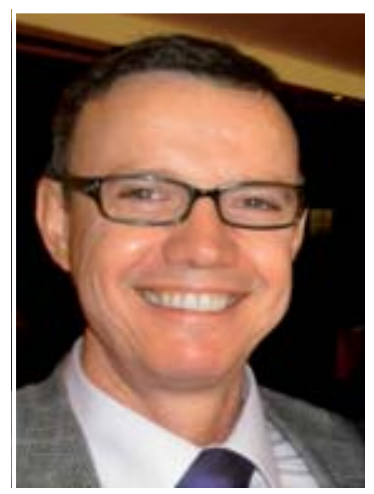

Vicente Hernández Franco Director

\title{
el maestro, un líder silencioso
}

ivimos tiempos de crisis. Ser maestro se está volviendo una profesión socialmente maltratada y que presenta un alto grado de indefensión.

Distintos medios contribuyen a que se instale en la opinión pública la creencia

de que el profesorado es el culpable de las deficiencias de nuestro sistema educativo y por extensión de muchos de los problemas sociales que nos afectan. Hay quien llega a insinuar que la alta tasa de paro de nuestro país es consecuencia de lo mal preparados que están sus maestros y profesores. Vemos cómo se marchita la delicada flor de su reputación social difundiendo que a estas profesiones sólo acceden los académicamente mediocres, aquellos licenciados que no son capaces de conseguir otros puestos de trabajo mucho mejor retribuidos, meros oportunistas sin vocación alguna que se dedican a la enseñanza como último recurso para asegurarse un trabajo estable y para disfrutar de periodos de vacaciones más largos que en ninguna otra profesión. Aparte de ser esencialmente falsa, esta apreciación es una simplificación cargada de prejuicios de una realidad socioprofesional muy compleja, con raíces históricas muy profundas que no se pueden obviar y cuya transformación no se puede hacer en sólo una generación.

En estos momentos en que está a punto de aprobarse y entrar en vigor una nueva Ley de Educación, tenemos que volver a poner de manifiesto que los cambios que nuestra escuela necesita para enfrentarse a las nuevas condiciones sociales, culturales y tecnológicas no pueden hacerse desde un enfoque de arriba abajo. No basta con prescribirle normativamente al profesorado qué debe cambiar y cómo hacerlo, y controlar los cambios mediante reglamentos y sanciones. Este modo de entender los procesos de cambio es - como nos muestra la pedagogía comparada - un procedimiento que simplemente no es funcional y está abocado al fracaso. Las escuelas de hoy, y cada aula en particular, necesitan maestros y profesores que sean expertos en liderazgo pedagógico; que sepan aplicar el nuevo conocimiento que actualmente tenemos sobre el aprendizaje, por ejemplo desde las neurociencias, para enseñar el currículo escolar de acuerdo con la forma real en que los seres humanos aprenden. Simplemente no se pueden cambiar las escuelas sin la profunda participación e implicación de los docentes y sin tener en cuenta lo que saben y aprenden continuamente en su ejercicio profesional. Y para ello es condición necesaria, como han insistido en recordar durante todo el proceso de gestación y tramitación parlamentaria de esta Ley nuestros maestros y profesores, que cualquier reforma que quiera tener éxito y perdurar en el tiempo tiene que elaborarse desde el máximo consenso de las fuerzas sociales y contar con su confianza e implicación como profesionales.

Termino expresando mi profundo reconocimiento y estima a los miles de maestras y maestros silenciosos que con su liderazgo pedagógico, resistiendo insultos y menosprecios inmerecidos, siguen siendo leales a su vocación de servicio, haciendo bien su trabajo y aplicando todos sus talentos con oficio y delicadeza. Expreso mi admiración por su entrega personal y porque continúan todavía disfrutando de su profesión, descubriendo en la mirada de sus alumnos de cualquier edad esa luz que sólo brilla cuando aprenden algo nuevo que les hace experimentar su potencial de crecimiento como seres humanos.

¡Qué nadie confunda este silencio con conformismo o trate de apropiárselo! Este mutismo intencional es un testimonio de duelo social y protesta ante nuestra clase política, que por lo que estamos conociendo, parece haber olvidado muchos de los buenos ejemplos de vida que en su día recibieron de sus maestros sobre lo que significa entregarse a una profesión como servicio al bien común. 